\title{
Green innovation in recycling - a preliminary analysis of reversed logistics in Norway
}

\section{Bente Flygansvær*}

Department of Accounting Auditing and Business Analytics,

BI Norwegian Business School,

N-0442 Oslo, Norway

Email: bente.flygansvaer@bi.no

*Corresponding author

\section{Robert Dahlstrom}

Department of Marketing,

Farmer School of Business,

Miami University,

Oxford, Ohio USA

Email: dahlstrf@muohio.edu

and

Department of Marketing,

BI Norwegian Business School, Oslo, Norway

\section{Arne Nygaard}

Kristiania University College,

Postboks 1155 Sentrum,

Kirkegaten 24-26, 0107 Oslo, Norway

Email: arne.nygaard@kristiania.no

and

Norwegian University of Science and Technology (NTNU),

Teknologivegen 22, 2815 Gjøvik, Norway

\begin{abstract}
There has been an exponential growth of new electronic products in the global consumer market. New electronic consumer products generate a growing need for new methods, processes and entrepreneurship in recycling. In this study, we examine how entrepreneurs involved in the recycling of electronic products innovate to create a more sustainable circular economy. The recycling system must take care of electronics that contains hazardous materials. Also, a recycling system should prevent the waste of potentially useful materials. Thus, entrepreneurship is crucial to improve the handling of toxic material and processing technology to reuse valuable elements. Innovation therefore is essential to facilitate a sustainable recycling process. In this study, we analyse entrepreneurial innovation in the light of the organisational structure of the recycling system. Following a study of 108 recycling entrepreneurs, competition and specific investments are found to be important factors that drive the sustainable innovation that make Norway one of the countries with the highest recycling rates of electronic and electric waste.
\end{abstract}


Keywords: electronics industry; sustainable entrepreneurship; circular systems; ecological innovation; reverse logistics; reverse distribution; competition; specific investments; competitive advantage; electrical and electronic equipment waste; WEEE; corporate entrepreneurship; Norway.

Reference to this paper should be made as follows: Flygansvær, B., Dahlstrom, R. and Nygaard, A. (2019) 'Green innovation in recycling a preliminary analysis of reversed logistics in Norway', World Review of Entrepreneurship, Management and Sustainable Development, Vol. 15, No. 6, pp.719-733.

Biographical notes: Bente Flygansvær is an Associate Professor at BI Norwegian Business School. She received her Dr. Oecon degree from the Norwegian School of Economics and Business Administration (NHH) in 2006. She teaches and publishes within the areas of recycling, logistics and supply chain management. She has also worked for several years in industry, including both the private and public sector.

Robert Dahlstrom is the Joseph C. Seibert Professor of Marketing in the Farmer School of Business at Miami University. He is also an adjunct faculty of marketing at BI-Norwegian Business School. Since receiving his $\mathrm{PhD}$ in Marketing from the University of Cincinnati, he has published articles in the Journal of Marketing Research, the Journal of Marketing, the Journal of the Academy of Marketing Science and elsewhere. His research employs logic from institutional economics and related governance theories to investigate triple bottom line performance. His book titled Sustainable Marketing was published in 2018 by the Chicago Business Press.

Arne Nygaard is a Professor at Kristiania University College and at the Norwegian University of Science and Technology (NTNU). He received his Dr. Oecon degree from the Norwegian School of Economics and Business Administration (NHH) in 1992. He is the author of more than 50 papers, more than 30 papers in international refereed journals, six books and, comments and articles on a wide range of economic and business-related topics in the international and Norwegian press.

\section{Introduction}

Reverse logistics should facilitate handling of toxic material in electronic and electric products (WEEE). Furthermore, reverse logistics must improve recycling of valuable components and elements to avoid disposal. Preferably, the reverse logistics systems should improve reuse and recycling as sustainable alternatives to energy recovery or disposal (Figure 1). The entrepreneurship and innovation to move up the waste pyramid are paramount to a sustainable reversed logistics system. This article analyses and discuss the impact of specific investments in technology and knowledge to recycle and reuse as much of WEEE as possible. Innovation to move up in the waste pyramid (Figure 1) decreases the greenhouse effects, reduces pollution, preserves valuable materials and ultimately reduce the ecological footprint for generations to come. 
Figure 1 Entrepreneurship and innovation to move up in the recycling pyramid (see online version for colours)

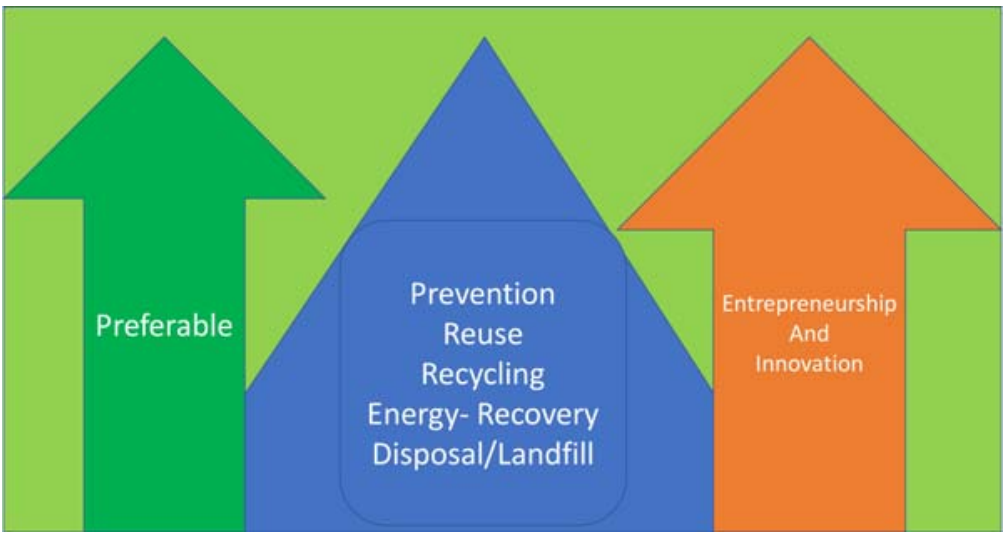

Global warming, biological diversity, waste and pollution are modern-day issues discussed in every boardroom. The same issues are important management challenges in the consumer electronics industry. Sthiannopkao and Wong (2012) estimate a growth in electrical and electronic equipment waste of $5-10 \%$ each year in the years to come. Today, WEEE is one of the fastest growing waste streams in the EU and grows at 3-5\% each year (Eurostat, 2016). Electronic products may contain potentially harmful substances like lead, cadmium, beryllium, mercury, dioxins, fluids, ammonia and asbestos or brominated flame retardants. WEEE may contain about 1,000 hazardous substances that represent threats to health and the environment. At the same time, WEEE represents an interesting commercial market opportunity because of the valuable raw materials that recycling may re-supply back into the market. A ton of ore from a gold mine generates ca. 5 grams ( 0.18 ounce) of gold on average, whereas a ton of mobile phones can produce 150 grams (5.3 ounces) (Yoshikawa, 2008). In Norway, the electronics recycling company Renas is the empirical setting for this investigation. The company collected more than 60,000 tons of electronic waste in 2016 and $14 \mathrm{~kg}$ of pure gold was extracted from the waste (Renas, 2017). In a new smart phone, it might be more than 40 different metals. But the continuous variation, technological complexity and new products confronts the recycling companies like Renas and its franchisee collectors with new challenges to identify and collect metals for reuse back into the value chains.

Consequently, EU regulations promote collection and recycling operations through Council Directive 2002/96/EC (2003) on WEEE that has been in force since February 2003. The EU system should recommend collection operations so that consumers can return electronic waste free of charge. Therefore, development of sustainable entrepreneurship is the crucial change process that transforms used products back into the circular product life cycles (Tilley and Parrish, 2006). Corporate entrepreneurship is a crucial capacity that has the inherent potential to create necessary change in the new sustainable circular economy. The existing recycling industry is an important change agent that increases the level of sustainability as well as protects society from toxic hazards. Corporate entrepreneurship should generate improved products through research, development and ideas that ultimately augment sustainable performance in established business organisations, throughout the product life cycle. The capacity to accept risk, innovate, bring new products to the market and achieve first mover 
advantages ultimately drives this change (Barringer and Bluedorn, 1999). Although there has been strong growth in reverse logistics systems that recycle products, this context remains under-explored in research (Acaccia, et al., 2007). Reverse logistics is "the process of moving goods from their typical destination for the purpose of capturing value, or proper disposal" (Hawks, 2006). Reverse logistics thus involves 'activities related to returns avoidance, gatekeeping, disposal and all other after-market supply chain issues' (Tibben-Lembke and Rogers, 2002). The significant costs and increased impact of a growing electronics market associated with reversed logistics adds entrepreneurial focus to this complex part of the value chain. We suspect that the growing number of new electronic products in the market require new innovative recycling processes.

\subsection{Green entrepreneurship and innovation}

Green innovation is a sustainable idea, device or method that continuously combines social, environmental and economic impact and performance (Christensen and Overdorf, 2000). Sustainable innovation embodies the creative destruction of obsolete and dysfunctional technology that hurt economic growth, welfare (Schumpeter, 1943) and quality of life in general. Green innovation, though, is not only based on the actions of each individual firm in a network. Green innovation is a network response throughout the product lifecycle that confronts and replace obsolete and unsustainable conventional technology (Stark, 2006). Reversed logistics is a crucial part of the circular economy within the product lifecycle. Green innovation is driven by the growth of new products consumed in the market. New consumer products lead to new environmental risks, changed technological systems and methods. Reversed logistics therefore must constantly find new ways to recycle new products. The innovation in green recycling methods that makes it possible to move up in the recycling pyramid (Figure 1) therefore is essential. However, the shorter life cycle of electric and electronic consumer products constantly challenges the established value chains. New electronic and electric consumer products (EE) create a need for innovation of new recycling methods and techniques. Emerging green technology provided by the recycling system replaces obsolete products and methods manifested by the traditional linear 'take-make-waste' - industrial models (Mintzberg, 1978). Thus, disruptive and sustainable technological change ultimately alters the philosophy of business models (Christensen and Overdorf, 2000).

Figure 1 exhibits the recycling pyramid where the most preferable and sustainable option is either to reduce consumption or to reuse products. The least favourable alternative is to dispose products into landfills. Entrepreneurship in recycling is needed to achieve a more sustainable step upward in the pyramid to reuse resources back into the value chain. The recycling company Renas, the empirical context in this study recycled 97\% of EE waste in 2016 (Renas, 2017). Metals like iron, aluminium, lead, copper and gold went back into the value chain to produce new products instead of ending up in a disposal. To achieve a continuous preferable high recycling percentage (Figure 1), the company, its collectors and re-processing system must develop its competence and innovate methods to process new WEEE- products and components.

\subsection{Waste management and entrepreneurship}

The economic growth and high GNP per capita in Norway combined with a rapid technological development have increased the waste load. Simultaneously, and partly 
caused by the same driving factors there is a short life cycle of electronic products. In 2016 recycling systems collected about 146,000 tons of WEEE, representing 28 kilos electronic and electric waste per person (Renas, 2017).

Figure 2 The organisation of the system for recycling of electrical and electronic equipment waste (WEEE) in Renas (franchisor) (see online version for colours)

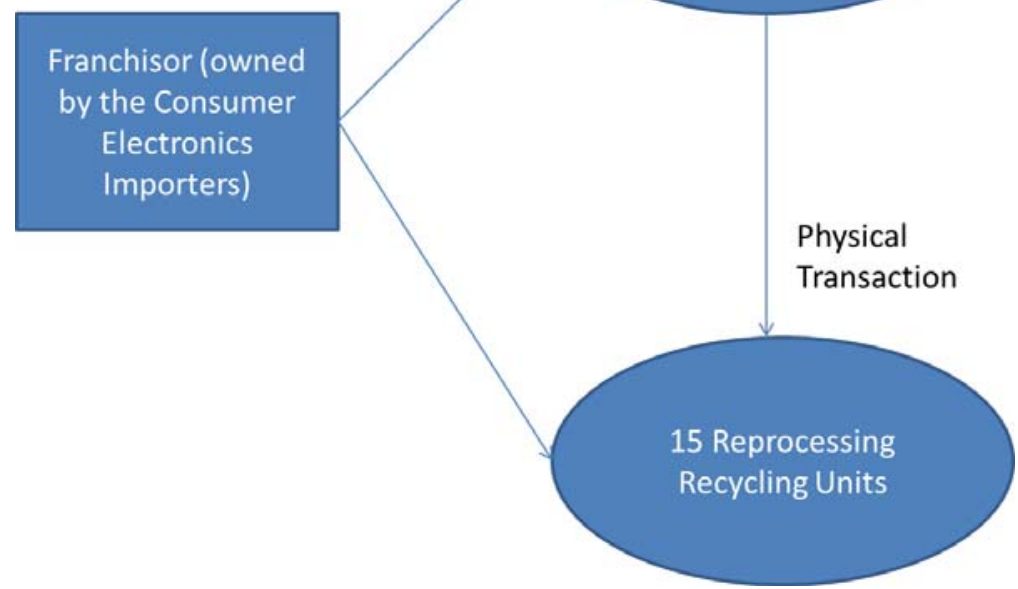

Because of the increased number of electronic and electric consumer products and their shorter life cycles, waste management is driven by changes in both technological factors and consumer preferences. The collection and distribution of waste is a complex, yet essential, part of the recycling system. To collect, store, separate and transport WEEE to the recycling facility is a complex process in the sustainable recycling system. Waste treatment in reversed logistics combines recovery and disposal operations. Waste recovery operations produce material that replaces other components. Alternatively, disposal is produced when this is not possible. Recycling operations recover and transform waste into new usage in the value chain. Reverse logistics is a unique set of methods reflecting contextual characteristics of the industry. Therefore, the technology that processes end-of-life WEEE-products should be different from other reversed logistics channels. Moreover, the development and innovation of unique and specific technology and knowledge (Williamson, 1985) is crucial to innovation and ultimately industry performance. Throughout the reversed distribution channel, there must be strong coordination between companies to orchestrate the process of transportation, warehousing, inventory control and recycling (Zeng, 2013). The coordination of the interorganisational structure of the reverse logistics system seems to produce better service levels and decreased distribution costs (Flygansvær et al., 2008). Governance mechanisms in reversed logistics coordinate the distribution process that manages human capital, information and the flow of materials (Aitken and Harrison, 2013). The organisation of the reversed logistics system should facilitate sustainable change. Hence, 
the reversed logistics system is faced by the dynamic need for innovations co-created between the collectors and the recycling units. The co-creation of new innovations might result from either cooperative efforts or technology rooted in the inter-organisational system. Both factors promote entrepreneurial drives that facilitate innovations. The growth in new EE- products, combined with the shorter life cycle of a consumer product, affects the business environment of the recycling system. In this study, we investigate the relationship between 156 electronic waste collectors and 15 reprocessing units, organised into the same franchise system by one franchisor representing importers of consumer electronics (Figure 2).

\section{Innovation and sustainable change}

\subsection{Specific investments}

Investments in competence and technology that are specifically directed to the application of new products and services are necessity in an industry exposed to continuous complexity and change. But these specific investments can be related to intra-organisational technology within the franchise system coordinated by the franchisor (Renas). Alternatively, the specific investments in knowledge and technology might also be related to the inter-organisational cooperation with the reprocessing units (Figure 2). In this study, we would like to investigate where the collectors prefer to allocate their specific investments to achieve innovation.

\subsection{Intra-organisational specific investments in the franchise system}

Research and development of new recycling technology in reversed distribution chains leads to unique assets with little or no outside value to the relationship between the parties. The risks associated to such specific investments make it crucial to safeguard both party's interests against behavioural opportunism (Williamson, 1985). Post-contractual opportunism is a systemic risk related to franchise systems that is the empirical context (Dahlstrom and Nygaard, 1999). A governance structure that secures both sides of the relationship tends to foster specific technology that generates innovation (Williamson, 1985). The organisational protection of both parties' economic interests facilitates co-creation in research and development. Williamson (1985) emphasises the strong incentives in a quasi-integrated bilateral relationship that strengthen the entrepreneurial drive. Corporations therefore establish long-term relationships with small businesses like franchisees that nurture the innovative organisational culture that is difficult to achieve in larger and more bureaucratic corporations. Also, there must be a strong commitment to sharing the resulting outcome. Sustainable technology in reversed logistics is an integrated operation of an established vertical distribution channel. Access to knowledge and competence development is a basic stepping stone to achieving sustainable technological change and improved recycling systems. The learning process is a know-how investment that affects entrepreneurship and ultimately innovation of services and products (Phana et al., 2009). These specific investments in technology and competence with other firms are costly for other firms to reproduce. Therefore, we hypothesise that: 
H1 The higher the level of intra-organisational specific investments within the franchise system, the higher the level of collector innovation.

\subsection{Specific investments in the collector and reprocessing relationship}

Furthermore, investment of know-how within a business-to- business relationship may be necessary to gain competitive advantages relative to other firms (Porter, 1991). Here, we analyse the context of inter-organisational relationship between collectors and the recycling company. Co-production of knowledge within this inter-organisational structure is crucial to provide new procedures, technologies and reuse of elements from the recycling system. This technology and competence is unique to the relationship (Williamson, 1985). Larger corporations often quasi-integrate R\&D operations to nurture and motivate innovation. Specific investments often develop in interaction between parties and create the environment for inter-organisational entrepreneurship. Both human capital theory (Becker, 1964) and resource-based theory (Montgomery, 1995) consistently predict that co-production of specific entrepreneurial competence promotes innovation (Bosma et al., 2004). Therefore, we provide a hypothesis to further explore how a specific technology and competence within relationships affect innovation:

H2 The higher the level of inter-organisational specific investments, the higher the level of innovation in collector organisations.

\subsection{Competitive intensity and innovations}

Competition should significantly affect corporate entrepreneurship and innovation (Porter, 1980). The intensity of competition promotes nurtures and drives corporate entrepreneurship. Entrepreneurship might involve innovation of new business models, organisational structures, new products, industries or differentiation of existing products. Competitive intensity increases the motivation to change technology, products, markets or business models (Ireland et al., 2009). Management is motivated by competition that directs attention to the effective use of time and resources. Hart (1983) suggests that competitive intensity curbs opportunistic behaviour and managerial slack in the organisation. Consequently, competition controls agency problems that cause opportunism. Competitive intensity forces management focus on innovation as a response to the competitive environment (Machlup, 1967). Less competitive drive creates a culture of opportunism, shirking and free riding (Nygaard and Myrtveit, 2000). Shirking and opportunism subsequently lead to lesser innovation and performance. Furthermore, higher competitive intensity also reduces the need for managerial monitoring of the cooperation between the two parties. Furthermore, competition nurtures the exchange of knowledge and new ideas among the competitors in the market (Ingram and Inman, 1996). Consequently, we assume that competitive intensity affects the level of innovation:

H3 The more intense the competition, the higher the level of collector innovation. 


\section{Methodology}

The logistics collector company represents the electrical and electronic (EE) industry. A membership requires that the EE-company delegates its producer responsibility to the recycling company. Norwegian law promotes producer responsibility that is established as a part of, and implies many obligations, i.e. to develop recycling technology and competence. Thus, the Norwegian context might nurture entrepreneurial sustainability (Dana, 2017). The main legal obligation is to ensure that the producer (or importer) takes responsibility for their products when they are defined as being at end-of-life, and that they make sure that EE-equipment is recycled and that no hazardous materials or substances are released into the environment. The Norwegian government has defined an end-of-life collection level goal fixed at 80\% for WEEE (European Commission, 2016). When the recycling companies take on this responsibility for their members, they charge a membership fee, and use this funding to buy services from the recycling industry (or reclamation). Services include many reclamation activities like collection, accumulation, sorting, handling, transportation, dismantling and recycling. The recycling company RENAS recycled $97 \%$ of all electronic equipment waste in 2016 (Renas, Environment Report 2016). Only $1.3 \%$ of the waste went to landfill the same year.

The collector company is an actor in the recovery network that performs a selection of these activities, including collection, accumulation, sorting, handling and transportation. The collectors' task is to identify users of EE-equipment, and ensure that these products enter the recovery network when they are defined as waste (at end-of-life). The recycling company Renas has issued contracts to many collectors, as this network of agents must be represented throughout the entire country like a franchise system. The franchise contracts are standard across agents. The terms include compensation (a fixed price per ton of collected WEEE) and covers areas like the quality of handling, equipment for accumulation, collection and transportation, standards for the collection site locations, and how to provide information to the final user of EE-equipment. Following these terms, the agents can compete against each other for volumes, and the effectiveness and efficiency of their operations will determine their earnings.

We gathered data from a franchise network of countrywide businesses that collect process and recycle consumer WEEE (Glorvigen and Masliak, 2015). We invited 156 small and medium-sized collector franchisees to participate in the study. Both the collector companies and the recycling companies in the system employ their environmental knowledge and technology. The entrepreneurship in the application of industry and technological experience with toxic elements and the processing technology are vital knowledge to all firms in this industry. The entrepreneurial evolution of the collection and processing business focuses on separation and supply of WEEE. The empirical setting is a franchise system (Renas) owned by competing companies operating in the WEEE market in Norway and the franchisee collector firms that compete in the same market (Figure 2). The franchise company Renas delegates market collection operations to the 156 franchise units that are the empirical setting for this investigation. The franchisee units are profit dependent outlets that collect electronic waste and prepare products for recycling. The collecting companies face competition both for volume and location of WEEE. In the sample, there are 156 franchisee collector-companies that interact with 15 reprocessing companies that recycle the electronic products. The 
relationship between the collecting firms and the reprocessing units varies (Figure 2) in terms of cooperation, coordination, integration and competition. We therefore assume that the empirical setting offers sufficient variation to test the presented hypotheses.

An industry group of experts supported, guided and advised us through the data gathering process. They guided and controlled the face validity of the survey questions prior to the sampling procedure. The collector franchisee companies were contacted through an online software system (http://www.qualtrics.com). The manager of the collector company was the key informant. To increase the response rate, we contacted the no-response managers by phone and achieved 108 responding franchisees with complete survey response $(68 \%)$.

\subsection{Analysis and results}

The empirical context is a franchise system owned by the consumer electronics chains in the Norwegian market that have franchisee collector units that supply used products to the recycling system. It is a ceteris paribus setting for empirical analyses of recycling; where the business environment is relatively stable (Reve and Stern, 1986). We present the measurement model in the appendix. All constructs had satisfactory Cronbach's alpha above the $>0.7$ level, as can be seen in the enclosed appendix (Nunnally, 1978). Intra-organisational specific investment was measured by five items borrowed from John and Weitz (1988) and Anderson (1982). Inter-organisational specific investments were measured by five items from John and Weitz (1988) and Anderson (1982). Competitive intensity was measured by four items from Slater and Narver (1994). Innovation was measured by two items from Barringer and Bluedorn (1999). Table 1 exhibits the descriptive data from the model variables and the correlations among the scales.

Table 1 Correlation matrix for the measurement scales

\begin{tabular}{llcccc}
\hline & & 1 & 2 & 3 & 4 \\
\hline 1 & Intra-org. spec. & 1 & & & \\
2 & Inter-org. spec. & 0.69 & 1 & & \\
3 & Competition & 0.25 & 0.07 & 1 & 1 \\
4 & Innovation & 0.32 & 0.22 & 0.23 & \\
Descriptive statistics & & & & 3.07 \\
$\quad$ Mean value & 3.31 & 3.24 & 3.78 & 0.92 \\
& St. deviation & 0.66 & 0.61 & 0.74 & -0.50 \\
$\quad$ Skewness & -0.18 & -0.02 & -0.44 & 0.08 \\
$\quad$ Kurtosis & -0.37 & -0.37 & 0.18 & \\
\hline
\end{tabular}

The model test is summarised in Table 2. The model that explain innovation is significant $\left(\mathrm{F}\right.$-value $\left.=4.9^{* *}, \mathrm{p}<0.05\right)$. Hypothesis 1 suggested that intra-organisational specific investments affected the level of innovation. We found that the hypothesis is supported $(\beta=.258, \mathrm{p}<.05)$. Hypothesis 2 , suggesting that inter-organisational-specific investment affected innovation, was not supported in the statistical model. The test of hypothesis 3 , indicates that competitive intensity affects innovation $(\beta=.173, \mathrm{p}<.10)$. 
Table 2 Structural model test

\begin{tabular}{lcc}
\hline & \multicolumn{2}{c}{ Innovation } \\
\cline { 2 - 3 } & Coefficient & (T-value, -values $)$ \\
\hline Independent variables & \\
Intra-org. specific investments & 0.26 & $1.94^{* *}(\mathrm{p}=0.05)$ \\
Inter-org. specific investments & 0.33 & $0.255(\mathrm{p}=0.8)$ \\
Competition & 0.17 & $1.77^{*}(\mathrm{p}=0.08)$ \\
Summary statistics & Adj. $\mathrm{r}^{2}$ & 0.104 \\
F-value & $4.923^{* *}$ & \\
\hline
\end{tabular}

Note: $* *$ Correlation is significant at the 0.05 level.

*Correlation is significant at the 0.10 level.

\section{Discussion}

This empirical investigation explores the explanatory factors behind innovation in the reversed logistics industry in Norway. Our findings indicate that a combination of knowledge-driven strategy in system technology know-how and competitive intensity affect innovation in recycling. Therefore, both internal and external forces influence entrepreneurial strategies in the recycling business. Our findings underscore the crucial importance of system-related intra-organisational technological knowledge that stimulates innovation. Our study emphasises the value of specific investments in the technological in the company. Investments in technology and competence increased innovation inside the company. Furthermore, competitive advantages achieved through technology may promote better market performance. The increase in new EE consumer products entails the need for more innovative recycling solutions. This study focuses on specific investments in know-how (Williamson, 1985), within a context where the principal company (Renas) is a non-profit franchisor company owned by the importers of consumer electronics (Figure 2). The franchisor's relationships with the collectors are implicit, yet based on a common cultural framework of commitment to sustainable management and marketing (Basile, et al., 2016). The reversed specific distribution technology probably shifts the managerial attention from linear (take, make, dispose) to circular strategy (cradle to cradle) (Stahel, 2010). Finally, the conventional wisdom that competition drives innovation was supported by our data. It indicates that the incentives produced by external competitive pressures influence the recycling system.

\subsection{Limitations}

Our research has several weaknesses. We have applied a descriptive design that does not reveal the true causal structure in the theoretical model. Neither have we presented comparative data that could have indicated causal structures. Time asymmetry could have examined the relationship between relational and specific aspects of management decisions and the level of innovation. Unfortunately, we only had access to cross-sectional survey data. We therefore had no opportunities to analyse the time asymmetry in the data to reveal causal structures. The relationship between specific investments and innovation might be problematic. Protection of these assets is not 
necessary safeguarded through contracts and integrated control regimes. In other words, the process of investing in relationship-specific competence or assets might be caused by relational trust. To further explore the causal structure between specificity and inter-organisational structure, we need longitudinal and experimental data. The research also was based on data from key individual informants. This might produce biased data (Van Bruggen et al., 2002). Multiple informants from each company may perhaps have mitigated this problem Kumar, et al., 1993). The validity of this investigation should inspire other studies in other contexts and settings with longitudinal and experimental data (Haugland, et al., 2007).

\subsection{Managerial and research implications}

The study underlines the central effect of building competence into the relationship. The complexity and time needed to build system knowledge has a significant effect on the level of innovation in the company. Our data indicate that leadership attention should be focused on vitalisation of the system's technology and competence through intra-organisational knowledge within the franchise system. Relationship investments through inter-organisational specific capital, however, have no effect on entrepreneurial innovation. Although such relationships do not have any statistical connection to innovation, they still might be an important cultural aspect of the struggle to produce entrepreneurship in the organisations serving the sustainable recycling network. The managerial capacity to follow and analyse the competitive environment in this growing recycling industry is pivotal. Our research emphasises that innovation is closely related to competitive intensity. Competitive strategies therefore are essential to achieving long-term survival. Further research should look at explicit contractual aspects like incentives, ownership and other organisational structures (Eisenhardt, 1989). Other factors like norms, culture, trust and power might influence both the sustainable innovation climate and economic results. Furthermore, our context offered a stable and homogeneous empirical setting. However, the inquiry focused on the Norwegian model of reversed distribution that might be biased relative to other countries or markets. This area therefore needs more comparative and international research. The Norwegian model that we investigated here, however, is the most successful worldwide model in terms of the rate of recycling.

\section{Conclusions}

Innovation through technology and knowledge is crucial for achieving economic growth as well as for protecting the environment and people. Specific investments in knowledge and technology within the franchise system have significant effects. In contrast, our study revealed little or no effect of specific knowledge related to the inter-organisational context between the collector and the reprocessing units. Our findings indicate that transaction specific assets are important strategic factors in reaching environmental goals. Consistent with the transaction cost theory specific investments thrive in intra-organisational structures (Williamson, 1985). In inter-organisational contexts like the relationship between the collector and the reprocessing units, there are more difficult 
to safeguard specific investments in technology and knowledge. Consequently, our investigation did not identify effects of specific capital in inter-organisational structures.

Furthermore, this study emphasises the impact of competition on innovation. Competitive intensity drives the level of innovation. Porter $(1985, \mathrm{p} 207)$ points out that 'innovation grows out of pressure and challenge' that is embedded in the competitive situation. The findings show that competition promotes sustainable innovation and entrepreneurship.

\section{Acknowledgements}

The authors are listed at random as they contributed equally to the development of this article. We acknowledge Olga Masliak, Marius Glorvigen, Renas and Per Halvard Øveren for technical support, advice and assistance. We appreciate the valuable comments, questions and suggestions from the editor Leo-Paul Dana and the reviewers.

\section{References}

Acaccia, G.M., Michelini, R.C., Penzo, L.P. and Qualich, N. (2007) 'Reverse logistics and resource recovery: modelling car dismantling facilities', World Review of Entrepreneurship, Management and Sustainable Development, Vol. 3, Nos. 3-4, pp.284-301.

Aitken, J. and Harrison, A. (2013) 'Supply governance structures for reverse logistics systems', International Journal of Operations and Production Management, Vol. 33, No. 6, pp.745-764.

Anderson, E. (1982) Contracting the Selling Function: The Salesperson as Outside Agent or Employee, Unpublished $\mathrm{PhD}$ thesis, University of California, Los Angeles.

Barringer, B.R. and Bluedorn, A.C. (1999) 'The relationship between corporate factor affecting motivation market organizational facilitation and support and strategic management', Strategic Management Journal, Vol. 20, No. 5, pp.421-444.

Basile, G., Scozzese, G. and Ferri, M.A. (2016) 'Marketing and management: a complex adaptive system view', World Review of Entrepreneurship, Management and Sustainable Development, Vol. 12, Nos. 2-3, pp.134-148.

Becker, G. (1964) Human Capital: A Theoretical and Empirical Analysis, with Special Reference to Education, 3rd ed., The University of Chicago Press, Chicago.

Bosma, N., van Praag, M., Thurik, R. and de Wit, G. (2004) 'The value of human and social capital investments for the business performance of start-ups', Small Business Economics, October, Vol. 23, No. 3, pp.227-236.

Christensen, C.M. and Overdorf, M. (2000) 'Meeting the challenge of disruptive change', Harvard Business Review, March-April, Vol. 78, No. 2, pp.66-76.

Council Directive 2002/96/EC (2003) Waste Electrical and Electronic Equipment (WEEE), 27 January.

Dahlstrom, R. and Nygaard, A. (1999) 'An empirical investigation of ex post transaction costs in franchised distribution channels', Journal of marketing Research, Vol. 36, No. 2, pp.160-170.

Dana, L. (2017) Entrepreneurship in Western Europe: A Contextual Perspective, World Scientific, Montpellier Business School, France.

Eisenhardt, K.M. (1989) 'Agency theory: an assessment and review', Academy of Management Review, Vol. 14, No. 1, pp.57-74.

European Commission (2016) Waste Electrical and Electronic Equipment (WEEE) [online] http://ec.europa.eu/environment/index_en.htm (accessed 9 June 2016). 
European Statistics, Eurostat (2016) European Commission, Environmental Data Centre on Waste [online] http://ec.europa.eu/eurostat/web/waste/overview (accessed 5 February 2018).

Flygansvær, B., Gadde, L.E. and Haugland, S.A. (2008) Coordinated action in reverse distribution systems', International Journal of Physical Distribution and Logistics Management, Vol. 38, No. 1, pp.5-20.

Glorvigen, M. and Masliak, O. (2015) Inter-Organizational Relationship in RENAS Reverse Distribution System, Master thesis, BI Norwegian Business School, Oslo, Norway.

Hart, O. (1983) 'The market mechanism as an incentive scheme', Bell Journal of Economics, Autumn, Vol. 14, pp.366-382.

Haugland, S.A., Myrtveit, I. and Nygaard, A. (2007) 'Market orientation and performance in the service industry: a data envelopment analysis', Journal of Business Research, Vol. 60, No. 11, pp.1191-1197.

Hawks, K. (2006) 'What is Reverse Logistics?', Reverse Logistics Magazine, Winter/Spring, Georgia, USA.

Ingram, P. and Inman, C. (1996) 'Institutions, intergroup competition, and the evolution of hotel populations around Niagara Falls', Administrative Science Quarterly, Vol. 41, No. 4, pp.629-658.

Ireland, R.D., Covin, J.G. and Kuratko, D.F. (2009) Conceptualizing corporate entrepreneurship strategy', Entrepreneurship Theory and Practice, Vol. 33, No. 1, pp.19-46.

John, G. and Weitz, B. (1988) 'Forward integration into distribution: an empirical test of transaction cost analysis', Journal of Law, Economics and Organization, Vol. 4, No. 2, pp.337-335.

Kumar, N., Stern, L.W. and Anderson, J.C. (1993) 'Conducting interorganizational research using key informants', Academy of Management Journal, Vol. 36, No. 6, pp.1633-1651.

Machlup, F. (1967) 'Theories of the firm: marginalist, behavioral, managerial', American Economic Review, Vol. 57, No. 1, pp.1-33.

Mintzberg, M. (1978) 'Patterns in strategy formation', Management Science, Vol. 24, No. 9, pp.934-948.

Montgomery, C.A. (1995) 'Of diamonds and rust: a new look at resources', in Montgomery, C.A. (Ed.): Resource-Based and Evolutionary Theories of the Firm: Towards a Synthesis, pp.251-268, Springer International Publishing AG, Boston, MA.

Nunnally, J.C. (1978) Psychometric Theory, 2nd ed., McGraw Hill, New York.

Nygaard, A. and Myrtveit, I. (2000) 'Moral hazard, competition and contract design: empirical evidence from managerial, franchised and entrepreneurial businesses in Norway', Applied Economics, Vol. 32, No. 3, pp.349-356.

Phana, P.H., Wright, M., Ucbasarand, D. and Wee-Liang, T. (2009) 'Corporate entrepreneurship: current research and future directions', Journal of Business Venturing, Vol. 24, No. 3, pp.197-205.

Porter, M.E. (1980) Competitive Strategy: Techniques for Analyzing Industries and Competitors, Free Press, New York.

Porter, M.E. (1985) Competitive Advantage, Free Press, New York.

Porter, M.E. (1991) 'Towards a dynamic theory of strategy', Strategic Management Journal, Vol. 12, No. S2, pp.95-117.

Renas (2016) Miljø-rapport, Oslo.

Renas (2017) Annual Report 2016, Oslo.

Reve, T. and Stern, L.W. (1986) 'The relationship between interorganizational form, transaction climate, and economic performance in vertical interfirm dyads', Marketing Channels: Relationships and Performance, pp.75-102, Lexington Books, Lexington, MA, ISBN 0-669-13158-X. 
Schumpeter, J.A. (1943) Capitalism, Socialism, and Democracy, 6th ed., Routledge-Taylor \& Francis Group, London, UK.

Slater, S. and Narver, J. (1994) 'Does competitive environment moderate the market orientationperformance relationship?', Journal of Marketing, Vol. 58, No. 1, pp.46-55.

Stahel, W. (2010) The Performance Economy, Palgrave Macmillan, UK.

Stark, J. (2006) Global Product: Strategy, Product Lifecycle Management and the Billion Customer Question, Springer, London.

Sthiannopkao, S. and Wong, M.H. (2012) 'Handling e-waste in developed and developing countries: initiatives, practices, and consequences', Science of the Total Environment, October, Vol 40, pp.1147-1153.

Tibben-Lembke, R.S. and Rogers, D.S. (2002) 'Differences between forward and reverse logistics in a retail environment', Supply Chain Management: An International Journal, Vol. 7, No. 5, pp.271-282.

Tilley, F. and Parrish, B.D. (2006) 'From poles to wholes: facilitating an integrated approach to sustainable entrepreneurship', World Review of Entrepreneurship, Management and Sustainable Development, Vol. 2, No. 4, pp.281-294.

Van Bruggen, G.H., Lilien, G.L. and Kacker, M. (2002) 'Informants in organizational marketing research: why use multiple informants and how to aggregate responses', Journal of Marketing Research, Vol. 39, No. 4, pp.469-478.

Williamson, O.E. (1985) The Economic Institutions of Capitalism, Free Press, New York.

Yoshikawa, M. (2008) Urban Miners Look for Precious Metals in Cell Phones, Technology News, Reuters.

Zeng, A.Z. (2013) 'Coordination mechanisms for a three-stage reverse supply chain to increase profitable returns', Naval Research Logistics, Vol. 60, No. 1, pp.31-45. 


\section{Appendix}

Table A1 The measurement model and reliability measures

Scale items Likert 5-point scales

Cronbach's

alpha

Intra-org. specificity (John and Weitz, 1988; Anderson, 1982)

To what extent do you agree? Strongly disagree (1) - strongly agree (5).

We dedicate considerable time to learning the system within the company (name).

We invest a lot of time in learning about the company (name) operating procedures.

Their (name) recycling operations take considerable time to learn.

Their (name) operations are complicated.

A new employee must invest heavily to learn about their operations.

Inter-org. specificity (John and Weitz, 1988; Anderson, 1982)

To what extent do you agree? Strongly disagree (1) - strongly agree (5).

We dedicate considerable time to learning the system within the recycling company (name).

We invest a lot of time in learning about the recycling company (name) operating procedures

The recycling company's (name) recycling operations take considerable time to learn.

Their recycling company's (name) operations are complicated.

A new employee must invest heavily to learn about the operations of the recycling company.

Competitive intensity (Slater and Narver, 1994)

To what extent do you agree? Strongly disagree (1) - strongly agree (5).

Competition in our industry is hard.

There are many price wars in our industry.

Everything one company offers is easily copied by the others in the market.

Strong price competition characterises our industry.

Innovation (Barringer and Bluedorn, 1999)

How many products and services have your company introduced to the market the last five years?

None (1) or many (5) new lines of products or services.

Minor (1) or dramatic changes (5) in our products or services. 